\title{
Studies on Antagonistic Activity of Bacillus spp. against Nematode- Bacterial Wilt Complex in Tomato under Glasshouse Condition
}

\author{
H.S. Mahesha ${ }^{1}$, N.G. Ravichandra ${ }^{1}$, B.M.R. Reddy ${ }^{1}$, M.S. Rao $^{2}$ and Narase Gowda ${ }^{3}$ \\ ${ }^{1}$ Department of Plant Pathology, UAS, GKVK, Bengaluru, India \\ ${ }^{2}$ Division of Entomology and Nematology, IIHR, Hessaraghatta, Bengaluru, India \\ ${ }^{3}$ Department of Horticulture, UAS, GKVK, Bengaluru, India \\ *Corresponding author
}

\section{A B S T R A C T}

Keywords

Bacillus pumilus, $B$. megaterium, Meloidogyne incognita and Ralstonia solanacearum

Article Info

Accepted: 20 December 2017 Available Online: 10 January 2018
Two Bacillus spp. viz., B. pumilus-K-1 and B. megaterium-IIHR strains were tested under glasshouse as alone and in combination against $M$. incognita and $R$. solanacearum causing wilt complex in tomato. Combined application of B. pumilus-K-1 and B. megaterium-IIHR were found effective for the management of nematode bacterial wilt complex with the 50 per cent wilt incidence as compared to untreated control (100\%). However, combined application of $B$. pumilus-K-1 and B. megaterium-IIHR recorded minimum number of galls per root system (112) and number of egg masses per root system (47.33) as compared to untreated control (224.67 and 123.67) respectively, when compared to separate inoculation of B. pumilus-K-1 and B. megaterium-IIHR which recorded higher number of galls (121.67 and 131.67) and egg masses (72.33 and 64.00) respectively. Maximum plant growth parameters viz., plant height, fresh and dry shoot and root weight, root length were observed in case of combined application of B. megaterium-IIHR $+B$. pumilus-K-1 as compared to untreated control.

\section{Introduction}

Tomato (Solanum lycopersicum L.) is one of the most popular vegetable crops grown in the world, next to potato. Crop is being affected by many fungal, bacterial, viral and nematode pathogens. Among them, bacterial wilt caused by Ralstonia solanacearum and Root-knot nematode, Meloidogyne incognita (Kofoid \& White) Chitwood are the major constraints in production of tomato and other solanaceous crops.
The damage potential of $M$. incognita in tomato is as high as $27.2 \%$ yield loss in India (Jain et al., 2007) and $R$. solanacearum causes significant yield loss of 80 and $90 \%$ in brinjal and tomato respectively (Rao et al., 1975). In majority of the wilt complex, $M$. incognita acts as a predisposing agent for the entry of bacterium resulting in increased the severity of wilt. Further, it leads to resistance break down very quickly in presence of $M$. incognita (Jatala et al., 1975). 
Biological control of plant parasitic nematodes with antagonistic bacteria is a promising technique which may be incorporated in management of nematode and bacterial wilt complex.

In this context, the present investigations were taken up to study the efficacy of Bacillus spp. in the management of bacterium wilt-disease complex under glasshouse condition.

\section{Materials and Methods}

Extraction of second stage juveniles of Meloidogyne incognita and inoculation

Second stage juveniles were obtained from egg masses collected from heavily infected tomato plants by incubating large number of egg masses at room temperature in water. Before transplanting the seedlings, 1000 juveniles of $M$. incognita were inoculated to the pot by adding the nematode suspension into four holes made around the base of each plant and was covered with sterilized soil. Uninoculated control was maintained by pouring only water.

\section{Multiplication and inoculation of $R$.} solanacearum

The virulent culture of $R$. solanacearum was used for the inoculation. The tomato seedlings were inoculated by shearing few tertiary roots and dipping the roots into the virulent bacterial suspension containing $5.5 \times 10^{6} \mathrm{cfu}$ $/ \mathrm{ml}$ for 10 minutes.

Simultaneously inoculation of both pathogens viz., M. incognita and bacterial suspension $\left(5.5 \times 10^{6}\right.$ cells/ $\mathrm{ml} R$. solanacearum) was done. Seedlings dipped in water served as uninoculated control. Bio-agents were inoculated singly and in combination by pouring in the pot @ $50 \mathrm{ml} /$ pot.

\section{Treatment details}

$\mathrm{T}_{1}=$ Bacillus megaterium-IIHR on $M$. incognita

$\mathrm{T}_{2}=B$. megaterium-IIHR on $R$. solanacearum

$\mathrm{T}_{3}=B$. megaterium-IIHR on $M$. incognita and $R$. solanacearum

$\mathrm{T}_{4}=B$. pumilus $-\mathrm{K}-1$ on $M$. incognita

$\mathrm{T}_{5}=$ B. pumilus $-\mathrm{K}-1$ on $R$. solanacearum

$\mathrm{T}_{6}=$ B. pumilus $-\mathrm{K}-1$ on $M$. incognita and $R$. solanacearum

$\mathrm{T}_{7}=$ B. megaterium $-\mathrm{IIHR}+$ B.pumilus $-\mathrm{K}-1 \mathrm{on}$ M. incognita

$\mathrm{T}_{8}=$ B. megaterium $-\mathrm{IIHR}+$ B. pumilus $-\mathrm{K}-1$ on $R$. solanacearum

$\mathrm{T}_{9}=$ B. megaterium $-\mathrm{IIHR}+$ B.pumilus $-\mathrm{K}-1$ on $M$. incognita and $R$. solanacearum

$\mathrm{T}_{10}=$ Carbofuran @ 1g/kg soil on $M$. incognita

$\mathrm{T}_{11}=$ Streptomycin sulphate@ 500ppm + COC @ $0.25 \%$ on $R$. solanacearum

$\mathrm{T}_{12}=$ Carbofuran @ 1g/kg soil + Streptomycin sulphate@500ppm + COC @ $0.25 \%$ on $M$. incognita and $R$. solanacearum

$\mathrm{T}_{13}=$ Untreated control for $M$. incognita

$\mathrm{T}_{14}=$ Untreated control for $R$. solanacearum

$\mathrm{T}_{15}=$ Untreated control for $M$. incognita $+R$. solanacearum

$\mathrm{T}_{16}=$ Uninoculated control (Healthy)

Wilt Disease index $(\%)=$ No. of plants wilted/total no. of plants $\times 100$. 


\section{Results and Discussion}

Effect of Bacillus spp. on the development of galls, egg masses per root system and wilt incidence was presented in the Table 1 . The results indicates that, all the treatments significantly reduced number of galls and number of egg masses per root system compared to untreated control. Among the treatments, $\left(\mathrm{T}_{10}\right)$ comprising of carbofuran recorded the least number of galls and egg masses (76.33 and 39.33) followed by $\left(\mathrm{T}_{7}\right)$ containing B. megaterium-IIHR $+B$. pumilusK-1 (99.33 and 54.33) respectively. Similar results were obtained by Radwan et al., (2012) where in all the tested bioproducts, as well as carbofuran significantly reduced the number of root galls as compared with the untreated check. The number of galls decreased with the increase in the rate of bioproducts. At rate of $10 \mathrm{~g}(\mathrm{ml}) / \mathrm{kg}$ soil, B. megaterium achieved the highest significant reduction in the number of root galling followed B. cereus as compared with the untreated control.

Table.1 Effect of Bacillus spp. on bacterial wilt incidence and nematode development in tomato under glasshouse

\begin{tabular}{|c|c|c|c|}
\hline Treatments & Wilt incidence (\%) & $\begin{array}{c}\text { No. of galls per } \\
\text { root system }\end{array}$ & $\begin{array}{c}\text { No. of egg masses } \\
\text { per root system }\end{array}$ \\
\hline $\mathrm{T}_{1}$ & 0.00 & 136.33 & 78.33 \\
\hline $\mathrm{T}_{2}$ & 62.50 & 0.00 & 0.00 \\
\hline $\mathrm{T}_{3}$ & 75.00 & 121.67 & 72.33 \\
\hline $\mathrm{T}_{4}$ & 0.00 & 116.33 & 67.67 \\
\hline $\mathrm{T}_{5}$ & 50.00 & 0.00 & 0.00 \\
\hline $\mathrm{T}_{6}$ & 62.50 & 131.67 & 64.00 \\
\hline $\mathrm{T}_{7}$ & 0.00 & 99.33 & 54.33 \\
\hline $\mathrm{T}_{8}$ & 37.50 & 0.00 & 0.00 \\
\hline $\mathrm{T}_{9}$ & 50.00 & 112 & 47.33 \\
\hline $\mathrm{T}_{10}$ & 0.00 & 76.33 & 39.33 \\
\hline $\mathrm{T}_{11}$ & 25.00 & 0.00 & 0.00 \\
\hline $\mathrm{T}_{12}$ & 12.50 & 65.33 & 36.67 \\
\hline $\mathrm{T}_{13}$ & 0.00 & 283.33 & 135.33 \\
\hline $\mathrm{T}_{14}$ & 100 & 0.00 & 0.00 \\
\hline $\mathrm{T}_{15}$ & 100 & 224.67 & 123.67 \\
\hline $\mathrm{T}_{16}$ & 0.00 & 0.00 & 0.00 \\
\hline $\mathrm{SEm} \pm$ & -- & 4.60 & 4.84 \\
\hline $\mathrm{CD}$ at $5 \%$ & -- & 9.66 & 10.17 \\
\hline & & & \\
\hline
\end{tabular}


Table.2 Effect of Bacillus spp. on growth characters of tomato plant inoculated with $M$. incognita and $R$. solanacearum under glasshouse condition

\begin{tabular}{|c|c|c|c|c|c|c|}
\hline \multirow[t]{2}{*}{ Treatments } & \multicolumn{3}{|c|}{ Plant height $(\mathrm{cm})$} & \multicolumn{2}{|c|}{ Shoot weight(g) } & \multirow[t]{2}{*}{ Root length $(\mathrm{cm})$} \\
\hline & 30 DAP & 60 DAP & 90 DAP & $\operatorname{Fresh}(g)$ & $\operatorname{Dry}(g)$ & \\
\hline $\mathbf{T}_{1}$ & 38.33 & 54.33 & 63.67 & 49.45 & 18.75 & 23.33 \\
\hline $\mathbf{T}_{2}$ & 41.00 & 49.00 & 55.67 & 54.26 & 19.75 & 24.00 \\
\hline$\overline{\mathbf{T}_{3}}$ & 32.67 & 43.67 & 52.67 & 45.65 & 15.01 & 23.67 \\
\hline$\overline{\mathbf{T}_{4}}$ & 42.00 & 52.33 & 58.67 & 48.35 & 18.05 & 24.00 \\
\hline $\mathbf{T}_{\mathbf{5}}$ & 35.33 & 44.00 & 51.33 & 44.45 & 14.50 & 25.00 \\
\hline $\mathrm{T}_{6}$ & 32.67 & 43.00 & 52.00 & 46.50 & 15.00 & 28.00 \\
\hline $\mathbf{T}_{7}$ & 43.67 & 60.67 & 77.33 & 56.75 & 20.25 & 24.67 \\
\hline $\mathbf{T}_{8}$ & 44.00 & 63.00 & 81.00 & 57.25 & 21.00 & 30.67 \\
\hline $\mathbf{T}_{9}$ & 39.67 & 60.00 & 69.67 & 53.69 & 19.90 & 27.67 \\
\hline $\mathbf{T}_{10}$ & 32.00 & 40.33 & 51.67 & 48.65 & 18.25 & 26.00 \\
\hline $\mathbf{T}_{11}$ & 31.67 & 41.67 & 50.67 & 46.20 & 17.55 & 27.00 \\
\hline $\mathbf{T}_{12}$ & 34.00 & 43.00 & 51.33 & 45.00 & 14.75 & 22.67 \\
\hline $\mathbf{T}_{13}$ & 29.00 & 39.00 & 48.67 & 40.50 & 13.75 & 19.67 \\
\hline $\mathbf{T}_{14}$ & 31.67 & 39.67 & 45.33 & 38.25 & 13.00 & 22.00 \\
\hline $\mathbf{T}_{15}$ & 30.00 & 40.00 & 49.00 & 36.85 & 12.50 & 18.67 \\
\hline $\mathbf{T}_{16}$ & 40.00 & 57.67 & 72.33 & 52.25 & 20.00 & 29.00 \\
\hline $\mathrm{SEm} \pm$ & 2.09 & 2.67 & 2.63 & 1.48 & 0.93 & 1.77 \\
\hline $\mathrm{CD}$ at $5 \%$ & 4.28 & 5.46 & 5.38 & 3.02 & 1.91 & 3.61 \\
\hline
\end{tabular}

The least wilt incidence of 25 per cent was observed in plants treated with streptomycin sulphate@ 500 ppm + Copper oxychloride @ 0.25 per cent followed by $\mathrm{T}_{8}$ consisting of $B$. megaterium-IIHR + B. pumilus-K-1@ $50 \mathrm{ml}$ per plant amounting to 37.50 per cent as compared to untreated control (100\%). These results are supported by the work of done by Lemessa and Zeller (2007) where plants inoculated with the antagonistic isolates $B$. megaterium B2G and fluorescent pseudomonads significantly reduced disease compared to the untreated control. Both strains reduced wilt incidence by $60 \%$ and $56 \%$, respectively.

The data on effect of different treatments on growth parameters was presented in the Table 2 . At 30 days after treatments, maximum plant height was recorded in B. megaterium$\mathrm{IIHR}+B$. pumilus $-\mathrm{K}-1\left(\mathrm{~T}_{8}\right)$ treated plants $(44.00 \mathrm{~cm})$ followed by $B$. megaterium-IIHR + B. pumilus-K-1on $M$. incognita $\left(\mathrm{T}_{7}\right), B$. pumilus-K-1 on $M$. incognita $\left(\mathrm{T}_{4}\right)$ amounting 
to 43.67 and $42.00 \mathrm{~cm}$ respectively. Similar results were observed at 60, 90 days after planting. Maximum fresh and dry shoot weight, fresh and dry root weight and root length was recorded in plants inoculated with B. megaterium-IIHR $+B$. pumilus-K-1on $R$. solanacearum $\left(\mathrm{T}_{8}\right)$. These results are supported by the findings of Dursun et al., (2001) effect of different bacterial strains viz., $B$. subtilis BA-142 and B. megaterium-GC improving $\mathrm{N}, \mathrm{P}, \mathrm{Mg}, \mathrm{Ca}, \mathrm{Na}, \mathrm{K}, \mathrm{Cu}, \mathrm{Mn}, \mathrm{Fe}$ and $\mathrm{Zn}$ uptake by the plants. The highest average fruit weight, fruit weight per plant and plant length, root length, dry and fresh weight were obtained from applications of $B$. megaterium- GC in tomato. This is because of PGPR strains that produce plant hormones, such as auxins and cytokinins, can stimulate plant cell elongation or cell division, and/or change bacterial 1-aminocyclopropane-1carboxylate (ACC) deaminase activity (Patten and Glick, 2002).

Based on above data it can be concluded that combined application of B. pumilus $-\mathrm{K}-1$ and $B$. megaterium-IIHR significantly reduced the nematode and bacterial wilt complex, simultaneously increased the growth of tomato under glasshouse condition.

\section{References}

Dursun, A., Melek, E. and Mesude, F.D., 2010. Effects of application of plant growth promoting bacterium on chemical contents, yield and growth of tomato (Lycopersicon esculentum L.) and cucumber (Cucumis sativus L.). Pakistan J. Bot. 42(5): 3349-3356.

Jain, R.K., Mathur, K.N. and Singh, R.V., 2007. Estimation of losses due to plant parasitic nematodes on different crops in India. Indian J. Nematol. 37: 219220.

Jatala, P., French, E.R. and Gutarra, L., 1975. Interrelationship of Meloidogyne incognita acrita and Pseudomonas solanacearum on potatoes. J. Nematol. 7: 325.

Lemessa, F. and Zeller, W., 2007. Screening rhizobacteria for biological control of Ralstonia solanacearum in Ethiopia. Biol. Control. 42: 336-344.

Patten, C.L. and Glick, B.R., 2002. Role of Pseudomonas putida indole acetic acid in development of the host plant root system. App. Envi. Microbiol. 68: 3795-3801.

Radwan, M.A., Farrag, S.A.A., AbuElamayem, M.M. and Ahmed, N.S., 2012. Biological control of the rootknot nematode, Meloidogyne incognita on tomato using bioproducts of microbial origin. Appl. Soil Ecol. 56: 58-62.

Rao, M.V.B., Sohi, H.S. and Tirao, S.K., 1975. Reaction of wilt resistance tomato varieties and lines to Pseudomonas solanacearum in India. Pl. Dis. Reptr. 59: 734-736.

\section{How to cite this article:}

Mahesha, H.S., N.G. Ravichandra, B.M.R. Reddy, M.S. Rao and Narase Gowda. 2018. Studies on Antagonistic Activity of Bacillus spp. against Nematode- Bacterial Wilt Complex in Tomato under Glasshouse Condition. Int.J.Curr.Microbiol.App.Sci. 7(01): 2711-2715. doi: https://doi.org/10.20546/ijcmas.2018.701.324 